\title{
Nitric oxide in guard cells as an important secondary messenger during stomatal closure
}

\section{Gunja Gayatri, Srinivas Agurla and Agepati S. Raghavendra*}

Department of Plant Sciences, School of Life Sciences, University of Hyderabad, Hyderabad, India

\section{Edited by:}

Emmanuel Baudouin, Université

Pierre et Marie Curie-Paris 6, France

\section{Reviewed by:}

Alex Costa, University of Milan, Italy Carlos García-Mata, Instituto de Investigaciones Biologicas Universidad Nacional de Mar del

Plata - CONICET, Argentina

\section{*Correspondence:}

Agepati S. Raghavendra,

Department of Plant Sciences,

School of Life Sciences, University of Hyderabad, Hyderabad, 500046, India

e-mail:as_raghavendra@yahoo.com asrs@@uohyd.ernet.in
The modulation of guard cell function is the basis of stomatal closure, essential for optimizing water use and $\mathrm{CO}_{2}$ uptake by leaves. Nitric oxide (NO) in guard cells plays a very important role as a secondary messenger during stomatal closure induced by effectors, including hormones. For example, exposure to abscisic acid (ABA) triggers a marked increase in NO of guard cells, well before stomatal closure. In guard cells of multiple species, like Arabidopsis, Vicia and pea, exposure to ABA or methyl jasmonate or even microbial elicitors (e.g., chitosan) induces production of NO as well as reactive oxygen species (ROS). The role of NO in stomatal closure has been confirmed by using NO donors (e.g., SNP) and NO scavengers (like cPTIO) and inhibitors of NOS (L-NAME) or NR (tungstate). Two enzymes: a L-NAME-sensitive, nitric oxide synthase (NOS)-like enzyme and a tungstate-sensitive nitrate reductase (NR), can mediate ABA-induced NO rise in guard cells. However, the existence of true NOS in plant tissues and its role in guard cell NO-production are still a matter of intense debate. Guard cell signal transduction leading to stomatal closure involves the participation of several components, besides NO, such as cytosolic $\mathrm{pH}, \mathrm{ROS}$, free $\mathrm{Ca}^{2+}$, and phospholipids. Use of fluorescent dyes has revealed that the rise in NO of guard cells occurs after the increase in cytoplasmic $\mathrm{pH}$ and ROS. The rise in $\mathrm{NO}$ causes an elevation in cytosolic free $\mathrm{Ca}^{2+}$ and promotes the efflux of cations as well as anions from guard cells. Stomatal guard cells have become a model system to study the signaling cascade mechanisms in plants, particularly with $\mathrm{NO}$ as a dominant component. The interrelationships and interactions of $\mathrm{NO}$ with cytosolic $\mathrm{pH}, \mathrm{ROS}$, and free $\mathrm{Ca}^{2+}$ are quite complex and need further detailed examination. While assessing critically the available literature, the present review projects possible areas of further work related to NO-action in stomatal guard cells.

Keywords: abscisic acid, cytosolic pH, elicitors, polyamines, phospholipids, reactive oxygen species, signal transduction

\section{INTRODUCTION}

Stomatal pores are the gateways for not only transpirational $\mathrm{H}_{2} \mathrm{O}$ loss but also entry of $\mathrm{CO}_{2}$ into leaves. Due to such dual role, the regulation of stomatal aperture, and yet maintenance of opening are essential to keep up the water balance and at the same

\footnotetext{
Abbreviations: $\mathrm{ABA}$, abscisic acid; $\mathrm{ABI} 1 / 2$, ABA-insensitive protein phosphfatase 2C type 1/2; cPTIO, 2-phenyl-4,4,5,5-tetramethyl imidazoline-1-oxyl 3-oxide; cADPR, cyclic ADP ribose; $\mathrm{CDPK}$, calcium-dependent protein kinase; $\mathrm{CO}$, carbon monoxide; $\mathrm{CO}_{2}$, carbon dioxide; cGMP, cyclic guanosine monophosphate; $\mathrm{DAO}$, diamine oxidase; DGK, diacylglycerol kinase; DAF-2DA, 4,5-diaminofluorescein diacetate; DAG, diacylglycerol; ExtCaM, extra cellular calmodulin; flg22, flagellin 22; GSNO, S-nitrosoglutathione; GAPDH, glyceraldehyde-3-phosphate dehydrogenase; GSH, glutathione; $\mathrm{H}_{2} \mathrm{~S}$, hydrogen sulfide; $\mathrm{H}_{2} \mathrm{O}_{2}$, hydrogen peroxide; MAPK, mitogen-activated protein kinase; MJ, methyl jasmonate; L-NNA, $N_{\omega}$ nitro-L-arginine; L-NAME, $N$-nitro-L-arginine methyl ester; NR, nitrate reductase; NADPH, Nicotinamide adenine dinucleotide phosphate; NO, nitric oxide; NOS, nitric oxide synthase; NIR, nitrite reductase; NOA, nitric oxide-associated; LPS, lipopolysaccharide; PAO, polyamine oxidase; PAMP, pathogen-associated molecular pattern; $\mathrm{PIP}_{2}$, phosphatidylinositol 4,5-bisphosphate; PA, phosphatidic acid; PLD, phospholipase D; PLC, phospholipase C; PP2C, type 2C protein phosphatase; ROS, reactive oxygen species; SA, salicylic acid; SNP, sodium nitroprusside; XOR, xanthine oxidoreductase; YEL, yeast elicitor; PYR/PYL/RCAR, pyrabactin resistance protein1/PYR-like proteins/regulatory components of ABA receptor.
}

time make $\mathrm{CO}_{2}$ available for photosynthesis. Stomatal opening and closure are mediated by the changes in turgor pressure of guard cells. Stomata open when guard cells are turgid and close when the guard cells are flaccid. As closed stomata restrict pathogen entry into leaves, stomata become key players also in defense response against several pathogens (Underwood et al., 2007; Melotto et al., 2008). Several factors modulate stomatal function, such as drought, light, high $\mathrm{CO}_{2}$, humidity, and plant hormones, such as ABA (all abbreviations listed on first page). Some of the plant hormones (ABA, MJ, ethylene), salicylic acid, polyamines and even elicitors (mostly microbial) cause stomatal closure, while auxins and cytokinins promote stomatal opening (Bright et al., 2006; Acharya and Assmann, 2009; Alcázar et al., 2010; Jing et al., 2012; Ye et al., 2013).

NO has multifunctional roles in plants: stomatal movement, host-pathogen interactions, hormonal signaling during growth/development and adaptation to abiotic/biotic stress (Delledonne et al., 1998; Bright et al., 2006; Yan et al., 2007; Neill et al., 2008; Wilson et al., 2008, 2009; Siddiqui et al., 2011). In plants, $\mathrm{NO}$ can be a signal to induce secondary metabolite accumulation ( $\mathrm{Lu}$ et al., 2011) and to promote cell death 
(Gupta et al., 2011b; Bellin et al., 2013). The production of NO in stomatal guard cells has been known since several years (Desikan et al., 2002; Garcia-Mata et al., 2003). But the mechanisms of NO action and interaction with other signaling components in guard cells have been studied in detail, since only a few years. The rise in $\mathrm{NO}$ of guard cells is a common and dominant event during stomatal closure induced by several effectors and in different plants (Table 1).

Table 1 | The rise in NO of guard cells as a common event during stomatal closure induced by hormones, elicitors or environmental factors.

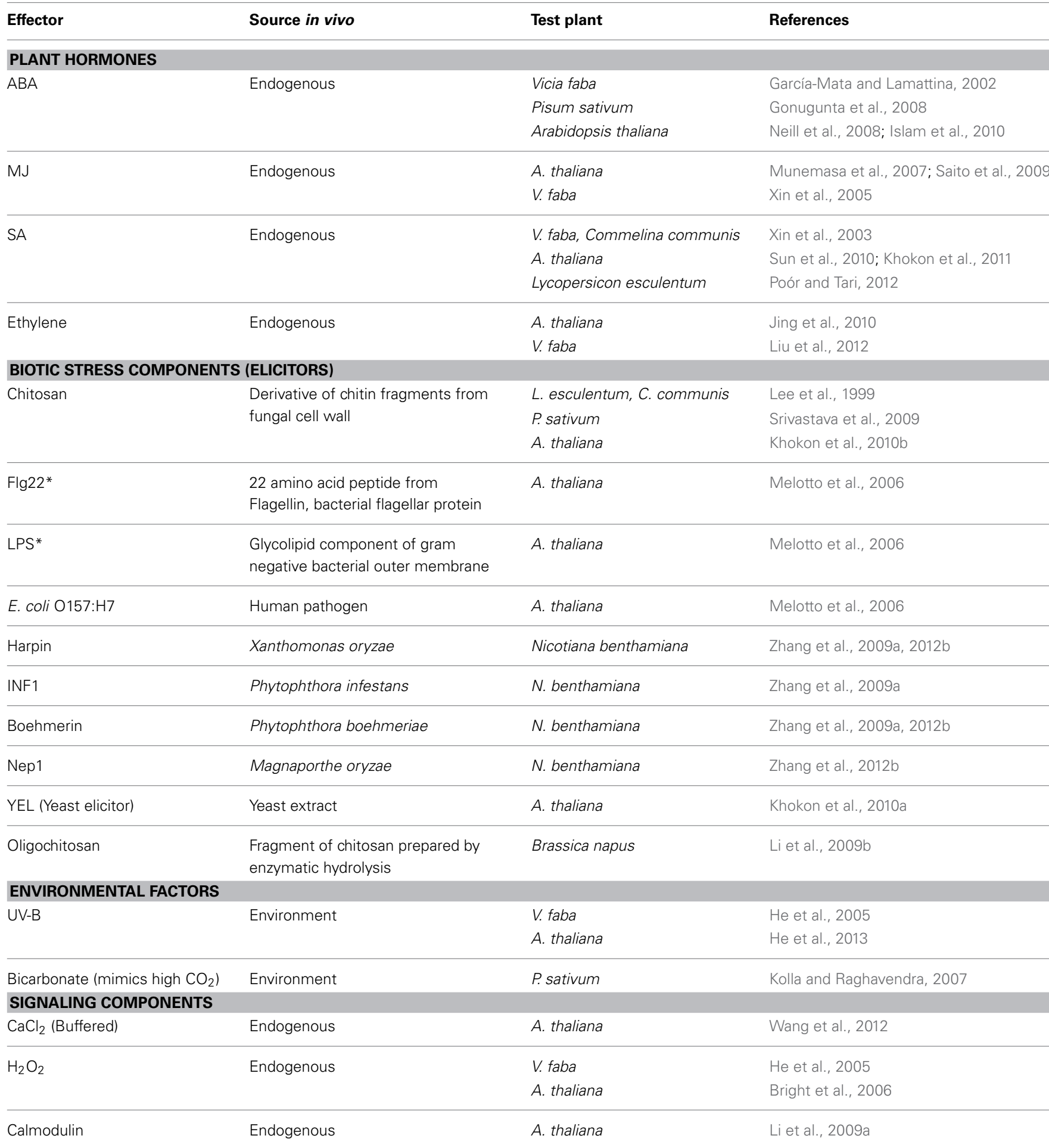

*PAMP- the term used for elicitors like flg22, LPS. 
There has been growing interest in NO as an essential signal molecule during stomatal closure, and plant growth/development, besides defense against pathogens. The ABA-induced stomatal closure is associated with a rise in NO as well as ROS of guard cells. The rise in NO causes elevation of free $\mathrm{Ca}^{2+}$ in guard cells, restriction of $\mathrm{K}^{+}$influx and promotion of anion efflux (Garcia-Mata et al., 2003; Sokolovski and Blatt, 2004), all resulting in loss of guard cell turgor and stomatal closure. This article emphasizes that NO is a common factor during stomatal closure induced by varying factors, including hormones, microbial elicitors (yeast/bacterial/fungal/pathogen) and abiotic environmental stresses. The possible sources of NO are described, highlighting the ambiguity on the role of true NOS in plants. A pathway of signal transduction, with the components involved in $\mathrm{NO}$ action, is proposed. Attention is drawn toward the interaction of $\mathrm{NO}$ with other signaling components in guard cells. Finally, a few of the emerging topics and unresolved questions, for further research are indicated.

In view of the large number of reports on the rise in $\mathrm{NO}$ of guard cells in relation to stomatal closure, we had to limit references to original articles, published in the last 5 years. There are excellent reviews covering the earlier work on the role of $\mathrm{NO}$ during stomatal closure (García-Mata and Lamattina, 2002, 2013; Neill et al., 2003, 2008; Desikan et al., 2004; Lamotte et al., 2005; Wilson et al., 2008, 2009; Hancock et al., 2011) and the importance of NO during the innate immunity responses of plants (Wendehenne et al., 2004; Leitner et al., 2009; Gaupels et al., 2011; Yoshioka et al., 2011). The importance of NO as a general signaling molecule in several processes of growth and development have been reviewed elsewhere (Durner and Klessig, 1999; Lamattina et al., 2003; Moreau et al., 2010; Baudouin, 2011; Fröhlich and Durner, 2011; Martínez-Ruiz et al., 2011; Astier et al., 2012; Simontacchi et al., 2013).

\section{HORMONES: ABA, ETHYLENE, METHYL JASMONATE}

The rise in $\mathrm{NO}$ is a common step during stomatal closure induced by hormones like ABA; or elicitors like chitosan; and even abiotic stress conditions (Table 1). Among the plant hormones, the perception and action of ABA is well characterized (Sirichandra et al., 2009; Cutler et al., 2010; Raghavendra et al., 2010). The stomatal closure induced by $\mathrm{ABA}$ involves a series of events, including a rise in reactive nitrogen species i.e., nitric oxide (NO). Additional signaling components that are involved are: reactive oxygen species (ROS, mostly $\mathrm{H}_{2} \mathrm{O}_{2}$ ), cytosolic $\mathrm{Ca}^{2+}$, cytoplasmic pH, G-proteins, protein kinases as CDPK and MAPK, protein phosphatases, phospholipases and sphingolipids (Gonugunta et al., 2008; Neill et al., 2008; Wang and Song, 2008; Umezawa et al., 2010; García-Mata and Lamattina, 2013). Extensive studies on guard cells of Arabidopsis, pea, Vicia faba and Commelina communis have established that NO is an essential signaling component during ABA-induced stomatal closure (Xin et al., 2005; Gonugunta et al., 2008, 2009; Neill et al., 2008). The increase in $\mathrm{NO}$ is usually associated with the elevated ROS levels, particularly $\mathrm{H}_{2} \mathrm{O}_{2}$, generated by plasma membrane $\mathrm{NADPH}$ oxidase. The role of several signaling components involved in NO production and stomatal closure induced by ABA was convincingly demonstrated by studies performed in Arabidopsis mutants (Table 2).
The impaired NO production by $\mathrm{ABA}$ in nial, nia2 mutants (Desikan et al., 2006) and in atrbohD/F mutant is an indication of the key roles of NR and NADPH oxidase, respectively (Bright et al., 2006).

The other hormones, which induce an increase in NO leading to stomatal closure, are ethylene and MJ. External application of ethephon (an ethylene-releasing compound) or 1aminocyclopropane-1-carboxylic acid (the precursor of ethylene) induced stomatal closure in a dose-dependent manner in Arabidopsis thaliana (Desikan et al., 2006). Ethylene-induced stomatal closure was associated with a rise in not only $\mathrm{NO}$, but also $\mathrm{H}_{2} \mathrm{O}_{2}, \mathrm{Ca}^{2+}$, and cytoplasmic pH (Jing et al., 2010, 2012). The precise order of these molecules during NO action and stomatal closure is not yet known. The effects of ethylene on NO level may be either direct or indirect through the modulation of endogenous ABA levels. This aspect needs additional experiments for confirmation.

MJ, a linolenic acid derivative, is as powerful as ABA in inducing stomatal closure, and elevating the levels of NO, besides ROS in guard cells (Gonugunta et al., 2009; Munemasa et al., 2011b). The role of NO as one of the signaling components during MJinduced stomatal closure is further confirmed by the decrease in NO production and stomatal closure by L-NAME in $V$. faba guard cells (Xin et al., 2005). The MJ or ABA-induced NO production was impaired in $r c n 1$ mutant of $A$. thaliana, deficient in the regulatory subunit of protein phosphatase 2A (RCN1) (Saito et al., 2008, 2009). However, SNP (a NO donor) induced stomatal closure along with rise in guard cell NO levels in $r c n 1$ mutant as well as in wild type.

\section{MICROBIAL ELICITORS}

Besides being gateways for water/ $\mathrm{CO}_{2}$, stomata can limit the invasion of pathogenic bacteria, and thus be a part of the plant innate immune system (Baker et al., 2010; Zeng et al., 2010). A burst in NO production has long been identified as one of the plant defense responses. Further, NO plays a very important role in cell death and activation of defense genes against plant pathogens (Delledonne et al., 2003; Romero-Puertas et al., 2004; GarciaBrugger et al., 2006). The protective role of NO doubles up, as it upregulates secondary metabolism, and levels of antimicrobial compounds (Wang and Wu, 2004; Zhang et al., 2012a). In view of such crucial role, the molecular events in plant cells, triggered by $\mathrm{NO}$, to help in innate immunity have been studied in detail. Compared to the extensive literature on the role of the NO-burst as a component of pathogen resistance, there is very limited work on the mechanism of NO-rise in guard cells, when exposed to elicitors/plant pathogens.

A typical effect of several elicitors is the marked stomatal closure and an increase in guard cell NO (Table 1). NO production was observed in guard cells of A. thaliana, Pisum sativum, and Nicotiana benthamiana in response to elicitors such as, PAMP, chitosan and oligochitosan (Melotto et al., 2006; Li et al., 2009b; Srivastava et al., 2009). In addition, other elicitors such as harpin, boehmerin, INF1, and Nep1 induced the production of NO in guard cells of $N$. benthamiana (Zhang et al., 2009a, 2012b). Impaired stomatal closure in response to elicitors by cPTIO (NO scavenger) or upon treatment with L-NNA (NOS inhibitor) 


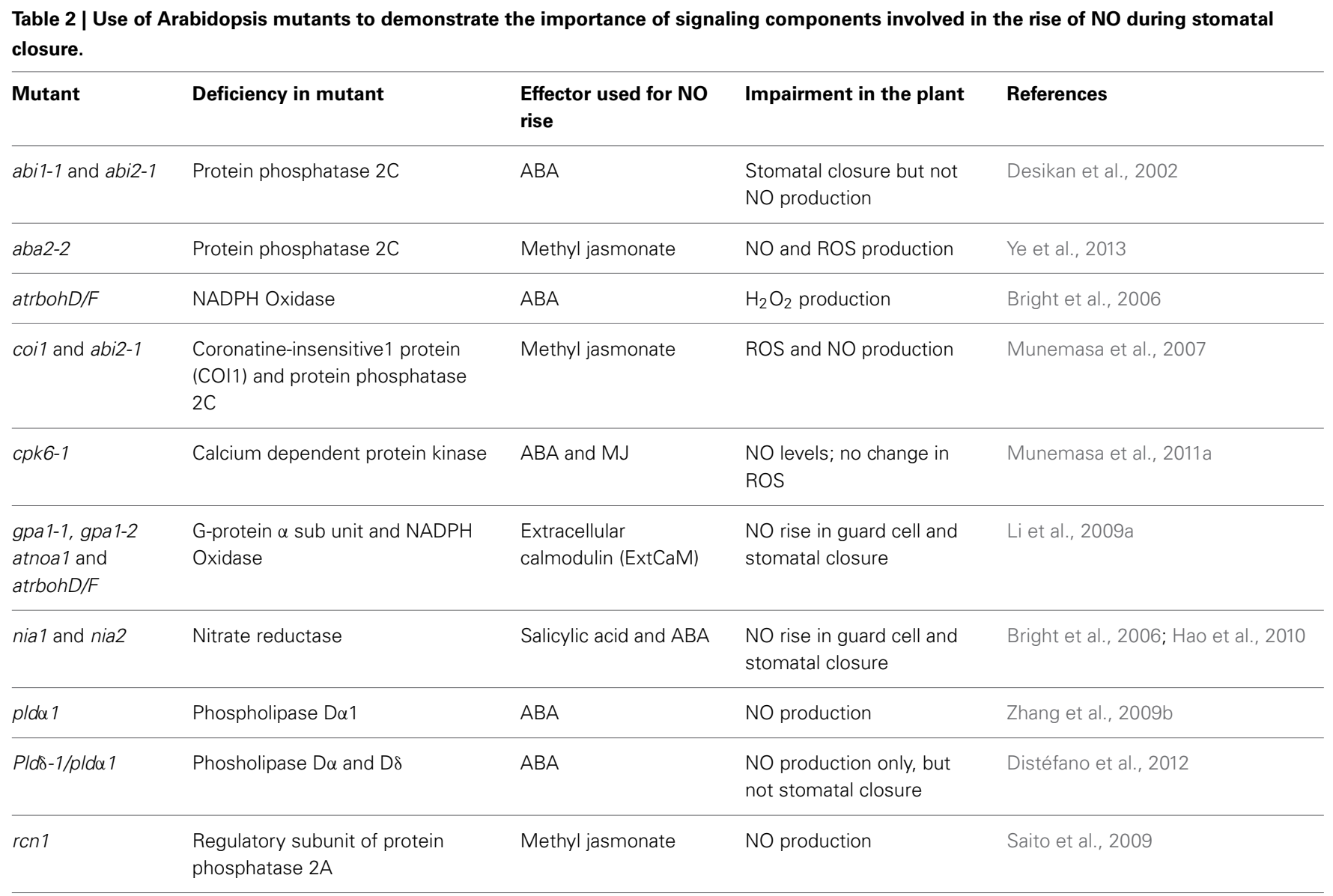

confirms the role of $\mathrm{NO}$ in stomatal signaling (Melotto et al., 2006; Khokon et al., 2010a,b; Zhang et al., 2012b).

The production of NO occurred downstream of ROS, during stomatal closure induced by chitosan (Srivastava et al., 2009; Khokon et al., 2010b). The signaling components identified with elicitor-induced stomatal closure and NO-rise in guard cells are: ROS/NADPH oxidases, G-proteins, vacuolar processing enzyme (Zhang et al., 2009a, 2010, 2012b). It is not clear if the signal transduction chain involving NO-rise and stomatal closure induced by different elicitors follows the same or a modified pathway.

\section{SALICYLIC ACID}

SA is a phenolic compound, known to play a key role in a wide range of physiological and developmental processes, such as thermogenesis, fruit ripening, ethylene synthesis and plant defense against pathogens (Loake and Grant, 2007). There have been early reports on the regulation by SA of stomatal movement (Manthe et al., 1992; Lee and Joon-Sang, 1998) and role of signaling molecules, such as superoxide radicals, $\mathrm{Ca}^{2+}, \mathrm{H}_{2} \mathrm{O}_{2}$, and NO in modulating SA-effects (Mori et al., 2001). The SA-induced $\mathrm{NO}$ production and stomatal closure was impaired by cPTIO (NO scavenger) in guard cells of $V$. faba (Xin et al., 2003) and Arabidopsis (Khokon et al., 2011) highlighting the importance of NO during responses to SA.

\section{PHOSPHOLIPIDS}

Phospholipids are major components of plasma membrane and have emerged as key signaling molecules (Meijer and Munnik, 2003; Testerink and Munnik, 2005; Wang, 2005). These phospholipids such as phosphatidic acid (PA), phosphatidylinositol 4,5-bisphosphate $\left(\mathrm{PIP}_{2}\right)$ and diacylglycerol (DAG) regulate a wide range of growth and developmental processes including ABA signaling, programmed cell death and defense response (Katagiri et al., 2005; Wang, 2005; Choi et al., 2008). Another group of phospholipids, which could potentially interact with NO, are sphingolipids (Guillas et al., 2013). The role of sphingolipids in relation to $\mathrm{NO}$-action on guard cells needs to be probed in detail.

Among the phospholipids, the effect of PA appears to be quite interesting. In plant tissues, PA generated by either PLC or PLD, can inactivate $\mathrm{K}^{+}$in channels and promote stomatal closure (Jacob et al., 1999; Uraji et al., 2012). The increase in the levels of PA in $V$. faba guard cells on exposure to $\mathrm{NO}$ and prevention of stomatal closure by inhibitors of either PLC or PLD suggested that NO might be involved in the production of PA and stomatal closure (Distéfano et al., 2008). Among the 12 PLD genes of Arabidopsis, $\operatorname{PLD} \alpha$ and PLD $\delta$ were shown to be involved in stomatal regulation (Zhang et al., 2009b; Distéfano et al., 2012; Uraji et al., 2012). Further description is in the section on "Signaling components in guard cells during NO action." 


\section{POLYAMINES}

Polyamines are ubiquitous, low molecular weight nitrogenous aliphatic compounds, which regulate several physiological and developmental functions (Kusano et al., 2008). Although the exact mechanisms are not completely understood, polyamines seem to help in plant adaptation to both biotic and abiotic stress (Alcázar et al., 2010). There are indications that polyamines interact with ABA (Alcázar et al., 2006, 2010). The limited reports on the increase in $\mathrm{NO}$ production by polyamines are ambiguous. Flores et al. (2008) observed that upregulation of arginase activity reduced the release of $\mathrm{NO}$ in A. thaliana mutants. In contrast, polyamines elevated NO production in tobacco BY-2 cells and Ocotea catharinensis somatic embryo cultures (SantaCatarina et al., 2007). Among the three polyamines tested, spermine was the most effective in inducing NO production, followed by spermidine and putrescine. Arginine, despite being a precursor molecule for the polyamine biosynthesis, could not increase NO (Tun et al., 2006).

The increase in NO of guard cells by polyamines may be related to $\mathrm{H}_{2} \mathrm{O}_{2}$. Oxidation of putrescine by DAO can facilitate ABAinduced $\mathrm{H}_{2} \mathrm{O}_{2}$ production (An et al., 2008). When polyamines are catabolized by DAO or $\mathrm{PAO}, \mathrm{H}_{2} \mathrm{O}_{2}$ is produced as one of the products (Alcázar et al., 2010). Though speculative, it appears reasonable to expect that the polyamine catabolic byproduct of $\mathrm{H}_{2} \mathrm{O}_{2}$ can elevate $\mathrm{NO}$, as $\mathrm{NO}$ acts downstream of relation to $\mathrm{H}_{2} \mathrm{O}_{2}$ during stomatal closure (Srivastava et al., 2009). Further studies are required to clarify if polyamines have a direct or indirect effect on the production of $\mathrm{NO}$ and ROS in stomatal guard cells.

\section{SOURCES OF NO}

The levels of NO within the cell, depends on the balance between production and scavenging. There is considerable work on the sources of NO in plant tissues, but very little information is available on the modes of scavenging NO. The possible sources of NO production can be categorized as enzymatic or non-enzymatic. Gupta et al. (2011a) summarized the literature on the sources of $\mathrm{NO}$ in plants, proposing that seven possible routes of NO production can be identified. In plants, the NR mediated NO production is accepted widely, while there is ambiguity about the role of a true NOS. Neill et al. (2008) reported that ABA-induced NO synthesis in guard cells could be driven by both NOS-like enzyme and NR activity. Nitrate can be reduced to nitrite and then to NO by NR, using $\mathrm{NADP}(\mathrm{H})$ as an electron source (Besson-Bard et al., 2008; Baudouin, 2011). However, the capability of NR in NO production is calculated to be only about $1 \%$ of its nitrate reduction capacity (Planchet et al., 2005). The root specific NiNOR found in purified plasma membranes of tobacco (Nicotiana tabacum) roots, has been proposed to be involved in the reduction of apoplastic nitrite to NO (Stöhr and Stremlau, 2006). The role of such plasma membrane bound nitrite: NO reductase (Ni-NOR) in guard cell NO production is yet to be critically assessed.

The NOS-induced NO production is well documented in animal systems, with reports of three isoforms: inducible, neuronal and endothelial NOS (Alderton et al., 2001). However, the existence of true NOS in plants is strongly questioned, because of two major reasons: (i) apparent absence of NOS in the genome of plants, including Arabidopsis; (ii) no convincing evidence for a protein, with NOS-like activity in higher plants. Although proteins with supposedly NOS activity are occasionally reported (Fröhlich and Durner, 2011), their exact identity is questionable. One of the NOS-like enzymes, described earlier (Moreau et al., 2010), turned out to be a GTPase and renamed as NOA. The role of NOA in NO production appears to be a possibility. Despite intense efforts, a true NOS is yet to be discovered in higher plants. The nearest finding is the report on arginine-dependent NOS-like activity in a green alga, Ostreococcus tauri (Foresi et al., 2010). The ambiguity on the source of NO extends to SA-mediated NOproduction, with reports implicating the importance of NOS-like enzyme (Xin et al., 2003; Sun et al., 2010) or NR (Zottini et al., 2007; Hao et al., 2010). Immediate attention is required to identify the precise enzymatic source of NO production in guard cells, and such information would be applicable to other plant tissues.

There is an additional possibility of NO production by nonenzymatic reactions. Two such instances are: (i) Reduction of nitrite to NO occurred under the acidic and highly reduced conditions, and such NO formation was not impaired by typical NOS inhibitors (Zweier et al., 1999); and (ii) Rapid production of NO from nitrite in the incubation medium, Hordeum vulgare (barley) aleurone layers further promoted by phenolic compounds (Bethke et al., 2004). However, the relevance of these non-enzymatic NO sources in guard cells are unclear, and these may not be as crucial as enzymatic ones.

Our current knowledge of biological scavenging mechanisms of $\mathrm{NO}$ in plants, is quite meagre. Being diffusible, $\mathrm{NO}$ can react with several molecules within the cell. Such decrease in NO, due to its highly reactive nature should be considered important. There are reports that GSH and plant hemoglobins, could scavenge NO (Perazzolli et al., 2004; Basu et al., 2010), but the exact enzymatic steps of NO conversion need to be elucidated. The nitrosylation of cellular proteins could be involved in the NO action as well as the maintenance of NO levels. For example, nitrosylation has been found to affect the activity of proteins, such as GAPDH (Lindermayr et al., 2005; Vescovi et al., 2013; Zaffagnini et al., 2013) and outward $\mathrm{K}^{+}$-rectifying channels (Sokolovski and Blatt, 2004).

\section{SIGNALING COMPONENTS IN GUARD CELLS DURING NO ACTION}

Several signaling components have been identified to act either upstream or downstream of NO. The role of different components was established by usually three sets of evidence: (i) Employing inhibitors or scavengers, (ii) Monitoring the components by suitable fluorescent dyes; and finally (iii) Validation by using mutants deficient in a given component of signal transduction chain (Table 2). The inhibitors related to NO are: $\mathrm{PPTO}$ (scavenger of NO), L-NAME (inhibitor of NOS) and tungstate (inhibitor of NR). In some studies, artificial NO donors such as SNP and GSNO are also used. Studies on real-time monitoring of NO production, during stomatal closure have demonstrated that $\mathrm{pH}$ and $\mathrm{ROS}$ of guard cells rise before that of $\mathrm{NO}$ and stomatal closure occurs subsequently. Such early rise in $\mathrm{pH}$ and ROS was observed during stomatal closure induced by ABA, MJ as well as chitosan (Suhita et al., 2004; Gonugunta et al., 2008, 2009; Srivastava et al., 2009). Studies using NO scavenger 
(cPTIO) or L-NAME and tungstate, inhibitors of "NOS-like" and NR prevented the NO production but not ROS during stomatal closure in epidermal strips. Among the signaling components: PYR/PYL/RCAR (ABA-receptor proteins), ABI1/2 (that help binding to receptor proteins), ROS (generated by NADPH oxidase), $\mathrm{pH}, \mathrm{G}$-proteins and PA/PLC/PLD $\alpha 1$ act upstream of NO rise (Sirichandra et al., 2009; Zhang et al., 2009b; Cutler et al., 2010). In contrast to the role of PLD $\alpha 1, \operatorname{PLD} \delta$ is reported at either upstream or downstream of $\mathrm{NO}$ production in guard cells (Distéfano et al., 2012; Uraji et al., 2012). Similarly, $\mathrm{Ca}^{2+}$ may act at both levels upstream and downstream of NO (Garcia-Mata et al., 2003; Gonugunta et al., 2008).

Unlike other reports, an intriguing observation was that ABI1 and ABI2 might act downstream of the NO in stomatal signaling by ABA in A. thaliana guard cells (Desikan et al., 2002). Studies with mutants deficient in ROS production (like $r b o h D / F$ ) and by inhibitors like DPI, confirmed the strong association between ROS and NO (Bright et al., 2006; Neill et al., 2008; Srivastava et al., 2009). The stomatal closure induced by $\mathrm{ABA}$ or $\mathrm{H}_{2} \mathrm{O}_{2}$ and associated $\mathrm{NO}$ production were impaired in nia1, nia2 double mutant (Bright et al., 2006). The NO production by microbial elicitors (boehmerin, harpin and INF1) was impaired in NbrbohA and NbrbohB single and double silenced plants confirming that ROS acted upstream of NO production (Zhang et al., 2009a). Similarly, limited stomatal closure and NO production in response to microbial elicitors (harpin, Nep1, boehmerin) in G-

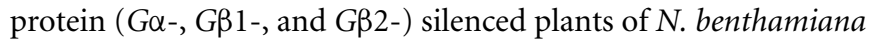
prove that G-proteins facilitate NO production, before stomatal closure (Li et al., 2009a; Zhang et al., 2012b).

The ability of PA to interact with ABI1 and NADPH oxidase (Zhang et al., 2004) implies that PA may act either upstream or downstream of NO. Distéfano et al. (2008, 2010) have established that the rise in $\mathrm{NO}$ causes elevation of PA which acts downstream of the NO during stomatal closure in $V$. faba. In the signaling scheme, proposed by Distéfano et al. (2010), ABA-induced NO activates PLC and/or PLD pathways to generate PA (Zhang et al., 2009b; Uraji et al., 2012). One of the products of PLC, namely $\mathrm{IP}_{3}$ can induce the release of $\mathrm{Ca}^{2+}$ from internal stores leading to stomatal closure. Attention needs to be drawn to reported participation of the PI3 and PI4 kinases (Kolla and Raghavendra, 2007) in bicarbonate-induced NO production. Such pathway is extremely interesting and may represent ROS-independent route of NO-production.

A direct well-known effect of NO is it's up-regulation of $\mathrm{Ca}^{2+}$ ion channel activity, promoting the release of $\mathrm{Ca}^{2+}$ from intracellular $\mathrm{Ca}^{2+}$ stores. Such rise in $\mathrm{Ca}^{2+}$ by $\mathrm{NO}$ was blocked by antagonists of guanylate cyclase and CADPR indicating that the downstream action of NO is mediated by both CADPR and cGMP. Parallely, the rise in cytosolic free $\mathrm{Ca}^{2+}$ inactivates $\mathrm{K}_{\text {in }}^{+}$channels (blocking $\mathrm{K}_{\text {in }}^{+}$currents) and activates $\mathrm{Cl}^{-}$ion channels (increasing anion currents), and both events lead to stomatal closure (GarciaMata et al., 2003; Sokolovski and Blatt, 2004; Sokolovski et al., 2005). A possible scheme of the signal transduction mechanism involving various components is presented in Figure 1.

Besides their key roles during the rise in $\mathrm{NO}$ and subsequent effects, several signaling components tend to interact (Table 3). The best and well known interactions of NO are with ROS, $\mathrm{Ca}^{2+}$

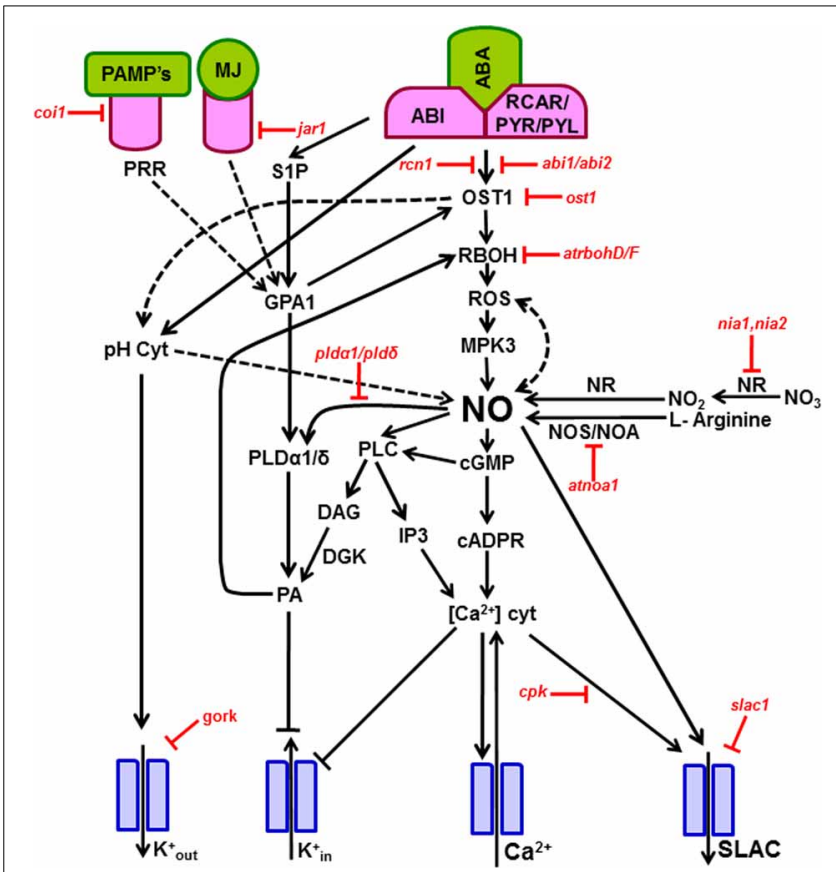

FIGURE 1 | Signal transduction mechanism involved during stomatal closure induced by ABA, MJ, and microbial elicitors. The

components/secondary messengers induced by either ABA or MJ or elicitors leading to the production of nitric oxide are indicated by forward arrows. The ion channels are represented by blue color. During stomatal signaling mechanism the guard cells upon perception of ABA, MJ, or elicitors, activate NADPH oxidase, leading to a burst of ROS, which leads to a $\mathrm{NO}$ burst. The elevation of $\mathrm{NO}$ raises the cytosolic free $\mathrm{Ca}^{2+}$, through up-regulation of cADPR and cGMP. In turn, the high cytosolic $\mathrm{Ca}^{2+}$ causes a down-regulation of $\mathrm{K}^{+}$inward channels and activation of outward anion channels, all leading to stomatal closure. Parallely, NO can increase the levels of PA via modulation of PLD and PLC. Several of these steps are validated by the use of mutants of Arabidopsis (indicated by red color), deficient in a particular signaling component. In the mutants, the relevant steps are blocked. The Arabidopsis mutants represented in this Figure are: abi1/abi2, ABA-insensitive (ABI1 and ABI2 protein phosphatases); atrbohD/F, A. thaliana NADPH oxidase catalytic subunit D/F; atnoa, $A$. thaliana nitric oxide-associated 1; coil, coronatine-insensitive 1 mutant; $c p k$, calcium-dependent protein kinase; gork, guard cell outward rectifying $\mathrm{K}^{+}$channel; jar1, JA response 1 mutant; nia1, nia2, Nitrate reductase double mutant; ost1, open stomata 1 kinase; plda 1/pld $\delta$, phospholipase $\alpha 1 /$ phospholipase $\delta$ double mutant; rcn 1, protein phosphatase $2 \mathrm{~A}$ regulatory $A$ subunit 1 ; slac1, slow anion channel-associated 1 mutant. $A$ description of these components is given in the section on "Signaling components in guard cells during NO action." Further information can be seen in Tables 1, 2. Abbreviations are listed in first page. The events demonstrated by experimental evidence are represented by solid arrows. The possible interactions/effects are indicated by broken arrows.

and $\mathrm{PA}$, and to some extent, with $\mathrm{pH}$. For e.g., $\mathrm{Ca}^{2+}$ stimulates $\mathrm{NO}$ production and $\mathrm{NO}$ in turn can rise $\mathrm{Ca}^{2+}$ levels (GarciaMata and Lamattina, 2007). Such dual role of $\mathrm{Ca}^{2+}$ is extremely interesting and warrants detailed examination. Similarly, the production of NO and PA promote the levels of each other (Zhang et al., 2009b). There may be a feedback regulation by NO of cytosolic $\mathrm{pH}$, since the rise in NO by SNP increased also the $\mathrm{pH}$ of guard cells (Gonugunta et al., 2008, 2009), but there is no 
Table 3 | Interactions of signaling components with NO during modulation of stomatal closure induced by different effectors.

\begin{tabular}{|c|c|c|c|c|}
\hline $\begin{array}{l}\text { Signaling } \\
\text { component }\end{array}$ & Type of interaction & Plant & Effector & References \\
\hline Cytosolic pH & Precedes NO production & Pisum sativum & ABA, MJ and Chitosan & Gonugunta et al., 2008, 2009 \\
\hline \multirow[t]{2}{*}{$\mathrm{H}_{2} \mathrm{O}_{2}$} & Promotes NO production & P. sativum & Chitosan & Srivastava et al., 2009 \\
\hline & & A. thaliana & ABA & Bright et al., 2006 \\
\hline $\mathrm{Ca}^{2+}$ & Increases NO production & Vicia faba & ABA & Garcia-Mata and Lamattina, 2007 \\
\hline PLD $\delta$ & Acts downstream of $\mathrm{NO}$ & A. thaliana & $A B A$ and $N O$ & Distéfano et al., 2012 \\
\hline \multirow[t]{2}{*}{$\mathrm{H}_{2} \mathrm{~S}$} & Depletes NO levels in guard cells & A. thaliana & $\mathrm{H}_{2} \mathrm{~S}$ & Lisjak et al., 2010 \\
\hline & Functions downstream of NO & V. faba & Ethylene & Jing et al., 2012 \\
\hline ABA & NO increases the sensitivity to $A B A$ & A. thaliana & NR and NOA & Lozano-Juste and León, 2010 \\
\hline MJ & Elevates endogenous ABA & A. thaliana & Methyl jasmonate & Ye et al., 2013 \\
\hline
\end{tabular}

convincing evidence of such regulation of guard cell $\mathrm{pH}$ by $\mathrm{NO}$ during stomatal closure.

The marked interactions between signaling components, involving NO, constitute a dynamic and complex regulatory network. Because of the complicated nature of signaling network and strong interactions among them, only a few attempts have been made to model these events. Li et al. (2006) presented a dynamic model of signaling components in which NO is produced by NR and NOS-like enzyme, in response to ABA, and the $\mathrm{Ca}^{2+}$ mobilized from intracellular sources, could induce stomatal closure. Similarly, Beguerisse-Díaz et al. (2012) proposed a model of interactions between NO and ethylene. These models need to be validated by experimental evidences.

\section{CONCLUDING REMARKS}

The available literature amply demonstrates that NO is a common signaling component and a converging step for events initiated by ABA, MJ, or elicitors. The upstream components of NO, which rise during $\mathrm{ABA}$ action, are broadly understood. For example, ABA binds to PYR/PYL/RCAR proteins and then to PP2C forming a trimeric complex. Due to the non-availability of PP2C, protein kinases are activated to trigger several downstream elements (Cutler et al., 2010; Raghavendra et al., 2010). However, the mechanism of reception and transduction of elicitor signals, particularly the elicitor-receptor interactions, and events leading to NO rise, are not clear and need detailed examination. The levels of NO in guard cells during stomatal closure are usually monitored by using suitable fluorescent dyes, such as DAF-2DA. But these

\section{REFERENCES}

Acharya, B. R., and Assmann, S. M. (2009). Hormone interactions in stomatal function. Plant Mol. Biol. 69, 451-462. doi: 10.1007/s11103008-9427-0

Alcázar, R., Altabella, T., Marco, F., Bortolotti, C., Reymond, M., Koncz, C., et al. (2010). Polyamines: molecules with regulatory functions in plant abiotic stress tolerance. Planta 231, 1237-1249. doi: 10.1007/s00425-010-1130-0

Alcázar, R., Cuevas, J. C., Patron, M., Altabella, T., and Tiburcio, A. F. (2006). Abscisic acid modulates polyamine metabolism under water stress in Arabidopsis thaliana. Physiol. Plant. 128, 448-455. doi: 10.1111/j.1399-3054.2006.00780.x measurements are being debated, since the specificity of fluorescent dyes has been questioned, due to their proneness to artifacts. Efforts are on to reassess and reconcile measurements of NO in plant tissues (Mur et al., 2011). The exact source of NO in plant tissues continues to be a controversial topic. Several possibilities have been identified, such as NR, NIR, NOS-like and even NOA, but the available literature is not convincing enough to assess the relative significance of the different sources (Neill et al., 2008; Gupta et al., 2011a).

A range of highly interesting topics are emerging, studies on which can be quite useful. Among these are: modulation of NO by endogenous plant hormones, such as ABA (Lozano-Juste and León, 2010), role and interaction with other gaseous molecules such as $\mathrm{H}_{2} \mathrm{~S}$ and $\mathrm{CO}$, termed gasotransmitters (García-Mata and Lamattina, 2013), and the post-translational modification of downstream proteins by NO or ROS or both (Yoshioka et al., 2011). In summary, further detailed work on the role and source of NO in guard cells promises to be a rewarding exercise and may provide information relevant to other plant tissues.

\section{ACKNOWLEDGMENTS}

The work is supported by a J C Bose National Fellowship (No. SR/S2/JCB-06/2006) to Agepati S. Raghavendra, from the Department of Science and Technology, New Delhi; and University Grants Commission-Junior Research Fellowship to Gunja Gayatri and Srinivas Agurla. We also thank DBT-CREBB, DST-FIST and UGC-SAP-CAS, for support of infrastructure in Department/School.
Alderton, W. K., Cooper, C. E., and Knowles, R. G. (2001). Nitric oxide synthases: structure, function and inhibition. Biochem. J. 357, 593-615. doi: 10.1042/0264-6021:3570593

An, Z., Jing, W., Liu, Y., and Zhang, W. (2008). Hydrogen peroxide generated by copper amine oxidase is involved in abscisic acid-induced stomatal closure in Vicia faba. J. Exp. Bot. 59, 815-825. doi: 10.1093/jxb/erm370

Astier, J., Kulik, A., Koen, E., BessonBard, A., Bourque, S., Jeandroz, S., et al. (2012). Protein Snitrosylation: what's going on in plants? Free Radic. Biol. Med. 53, 1101-1110. doi: 10.1016/ j.freeradbiomed.2012.06.032 
Baker, C. M., Chitrakar, R., Obulareddy, N., Panchal, S., Williams, P., and Melotto, M. (2010). Molecular battles between plant and pathogenic bacteria in the phyllosphere. Braz. J. Med. Biol. Res. 43, 698-704. doi: 10.1590/S0100879X2010007500060

Basu, S., Keszler, A., Azarova, N. A., Nwanze, N., Perlegas, A., Shiva, S., et al. (2010). A novel role for cytochrome c: efficient catalysis of S-nitrosothiol formation. Free Radic. Bio. Med. 48, 255-263. doi: 10.1016/i.freeradbiomed.2009. 10.049

Baudouin, E. (2011). The language of nitric oxide signalling. Plant Biol. 13, 233-242. doi: 10.1111/j.14388677.2010.00403.x

Beguerisse-Díaz, M., HernándezGómez, M. C., Lizzul, A. M., Barahona, M., and Desikan, R. (2012). Compound stress response in stomatal closure: a mathematical model of ABA and ethylene interaction in guard cells. BMC Syst. Biol. 6:146. doi: 10.1186/1752-0509-6-146

Bellin, D., Asai, S., Delledonne, M., and Yoshioka, H. (2013). Nitric oxide as a mediator for defense responses. Mol. PlantMicrobe Interact. 26, 271-277. doi: 10.1094/MPMI-09-12-0214-CR

Besson-Bard, A., Pugin, A., and Wendehenne, D. (2008). New insights into nitric oxide signalling in plants. Annu. Rev. Plant Biol. 59, 21-39. doi: 10.1146/annurev. arplant.59.032607.092830

Bethke, P. C., Badger, M. R., and Jones, R. L. (2004). Apoplastic synthesis of nitric oxide by plant tissues. Plant Cell 16, 332-341. doi: 10.1105/tpc.017822

Bright, J., Desikan, R., Hancock, J. T., Weir, I. S., and Neill, S. J. (2006). ABA-induced NO generation and stomatal closure in Arabidopsis are dependent on $\mathrm{H}_{2} \mathrm{O}_{2}$ synthesis. Plant J. 45, 113-122. doi: 10.1111/j.1365-313X. 2005.02615.X

Choi, Y., Lee, Y., Jeon, B. W., Staiger, C. J., and Lee, Y. (2008). Phosphatidylinositol 3- and 4-phosphate modulate actin filament reorganization in guard cells of day flower. Plant Cell Environ. 31, 366-377. doi: 10.1111/j.1365-3040.2007.01769.x

Cutler, S. R., Rodriguez, P. L., Finkelstein, R. R., and Abrams, S. R. (2010). Abscisic acid: emergence of a core signalling network. Annu. Rev. Plant Biol. 61, 651-679. doi: 10.1146/annurev-arplant042809-112122
Delledonne, M., Polverari, A., and Murgia, I. (2003). The functions of nitric oxide-mediated signalling and changes in gene expression during the hypersensitive response. Antioxid. Redox Signal. 5, 33-41. doi: 10.1089/152308603321223522

Delledonne, M., Xia, Y., Dixon, R. A., and Lamb, C. (1998). Nitric oxide functions as a signal in plant disease resistance. Nature 394, 585-588. doi: 10.1038/29087

Desikan, R., Cheung, K., Bright, J., Henson, D., Hancock, J. T., and Neill, Neill, S. J. (2004). ABA, hydrogen peroxide and nitric oxide signalling in stomatal guard cells. J. Exp. Bot. 55, 205-212. doi: 10.1093/jxb/erh033

Desikan, R., Griffiths, R., Hancock, J., and Neill, S. (2002). A new role for an old enzyme: nitrate reductase-mediated nitric oxide generation is required for abscisic acid-induced stomatal closure in Arabidopsis thaliana. Proc. Natl. Acad. Sci. U.S.A. 99, 16314-16318. doi: 10.1073/pnas.252461999

Desikan, R., Last, K., Harrett-Williams, R., Tagliavia, C., Harter, K., Hooley, R., et al. (2006). Ethyleneinduced stomatal closure in Arabidopsis occurs via AtrbohFmediated hydrogen peroxide synthesis. Plant J. 47, 907-916. doi: 10.1111/j.1365-313X.2006.02842.x

Distéfano, A. M., García-Mata, C., Lamattina, L., and Laxalt, A. M. (2008). Nitric oxide-induced phosphatidic acid accumulation: a role for phospholipases $\mathrm{C}$ and $\mathrm{D}$ in stomatal closure. Plant Cell Environ. 31, 187-194. doi: 10.1111/j.13653040.2007.01756.x

Distéfano, A. M., Lanteri, M. L., ten Have, A., García-Mata, C., Lamattina, L., and Laxalt, A. M. (2010). Nitric oxide and phosphatidic acid signalling in plants. Plant Cell Monogr. 16, 223-242. doi: 10.1007/978-3-64203873-0_15

Distéfano, A. M., Scuffi, D., GarcíaMata, C., Lamattina, L., and Laxalt, A. M. (2012). Phospholipase $\mathrm{D} \delta$ is involved in nitric oxideinduced stomatal closure. Planta 236, 1899-1907. doi: 10.1007/s00425-012-1745-4

Durner, J., and Klessig, D. F. (1999). Nitric oxide as a signal in plants. Curr. Opin. Plant Biol. 2, 369-374. doi: 10.1016/ S1369-5266(99)00007-2

Flores, T., Todd, C. D., TovarMendez, A., Dhanoa, P. K., Correa-Aragunde, N., Hoyos, M. E., et al. (2008). Arginasenegative mutants of Arabidopsis exhibit increased nitric oxide signalling in root development. Plant Physiol. 147, 1936-1946. doi: 10.1104/pp.108.121459

Foresi, N., Correa-Aragunde, N., Parisi, G., Caló, G., Salerno, G., and Lamattina, L. (2010). Characterization of a nitric oxide synthase from the plant kingdom: NO generation from the green alga Ostreococcus tauri is light irradiance and growth phase dependent. Plant Cell 22, 3816-3830. doi: 10.1105/tpc.109.073510

Fröhlich, A., and Durner, J. (2011) The hunt for plant nitric oxide synthase (NOS): Is one really needed? Plant Sci. 181, 401-404. doi: 10.1016/j.plantsci.2011.07.014

Garcia-Brugger, A., Lamotte, O. Vandelle, E., Bourque, S., Lecourieux, D., Poinssot, B., et al. (2006). Early signalling events induced by elicitors of plant defenses. Mol. PlantMicrobe Interact. 19, 711-724. doi: 10.1094/MPMI-19-0711

Garcia-Mata, C., Gay, R., Sokolovski, S., Hills, A., Lamattina, L., and Blatt, M. R. (2003). Nitric oxide regulates $\mathrm{K}^{+}$and $\mathrm{Cl}^{-}$channels in guard cells through a subset of abscisic acid- evoked signalling pathways. Proc. Natl. Acad. Sci. U.S.A. 100, 11116-11121. doi: $10.1073 /$ pnas. 1434381100

García-Mata, C., and Lamattina, L. (2002). Nitric oxide and abscisic acid cross talk in guard cells. Plant Physiol. 128, 790-792. doi: 10.1104/pp.011020

Garcia-Mata, C., and Lamattina, L. (2007). Abscisic acid (ABA) inhibits light-induced stomatal opening through calcium- and nitric oxide-mediated signalling pathways. Nitric Oxide 17, 143-151. doi: 10.1016/j.niox.2007.08.001

García-Mata, C., and Lamattina, L. (2013). Gasotransmitters are emerging as new guard cell signalling molecules and regulators of leaf gas exchange. Plant Sci. 201-202, 66-73. doi: 10.1016/j.plantsci.2012.11.007

Gaupels, F., Kuruthukulangarakoola, G. T., and Durner, J. (2011). Upstream and downstream signals of nitric oxide in pathogen defence. Curr. Opin. Plant Biol. 14, 707-714. doi: 10.1016/j.pbi.2011. 07.005

Gonugunta, V. K., Srivastava, N., and Raghavendra, A. S. (2009). Cytosolic alkalinization is a common and early messenger preceding the production of ROS and NO during stomatal closure by variable signals, including abscisic acid, methyl jasmonate and chitosan.
Plant Signal. Behav. 4, 561-564. doi: 10.4161/psb.4.6.8847

Gonugunta, V. K., Srivastava, N., Puli, M. R., and Raghavendra, A. S (2008). Nitric oxide production occurs after cytosolic alkalinization during stomatal closure induced by abscisic acid. Plant Cell Environ. 31, 1717-1724. doi: 10.1111/j.13653040.2008.01872.x

Guillas, I., Puyaubert, J., and Baudouin, E. (2013). Nitric oxide sphingolipid interplays in plant signalling: a new enigma from the sphinx. Front. Plant Sci. 4:341. doi: 10.3389/fpls.2013.00341

Gupta, K. J., Fernie, A. R., Kaiser, W. M., and van Dongen, J. T. (2011a). On the origins of nitric oxide. Trends Plant Sci. 16, 160-168. doi: 10.1016/j.tplants.2010.11.007

Gupta, K. J., Igamberdiev, A. U., Manjunatha, G., Segu, S., Moran, J. F., Neelawarne, B., et al. (2011b). The emerging roles of nitric oxide (NO) in plant mitochondria. Plant Sci. 181, 520-526. doi: 10.1016/j.plantsci.2011.03.018

Hancock, J. T., Neill, S. J., and Wilson, I. D. (2011). Nitric oxide and ABA in the control of plant function. Plant Sci. 181, 555-559. doi: 10.1016/j.plantsci.2011.03.017

Hao, F., Zhao, S., Dong, H., Zhang, H., Sun, L., and Miao, C. (2010). Nial and $\mathrm{Nia} 2$ are involved in exogenous salicylic acid-induced nitric oxide generation and stomatal closure in Arabidopsis. J. Integr. Plant Biol. 52, 298-307. doi: 10.1111/j.17447909.2010.00920.x

He, J.-M., Ma, X.-G., Zhang, Y., Sun, T.-F., Xu, F.-F., Chen, Y.-P., et al. (2013). Role and interrelationship of $\mathrm{G} \alpha$ protein, hydrogen peroxide, and nitric oxide in ultraviolet B-induced stomatal closure in Arabidopsis leaves. Plant Physiol. 161, 1570-1583. doi: 10.1104/pp.112. 211623

He, J.-M., Xu, H., She, X.-P., Song, X.-G., and Zhao, W.-M. (2005). The role and the interrelationship of hydrogen peroxide and nitric oxide in the UV-B-induced stomatal closure in broad bean. Funct. Plant Biol. 32, 237-247. doi: 10.1071/FP04185

Islam, M. M., Munemasa, S., Hossain, M. A., Nakamura, Y., Mori, I. C., and Murata, Y. (2010). Roles of AtTPC1, vacuolar two pore channel 1, in Arabidopsis stomatal closure. Plant Cell Physiol. 51, 302-311. doi: $10.1093 / \mathrm{pcp} / \mathrm{pcq} 001$

Jacob, T., Ritchie, S., Assmann, S. M., and Gilroy, S. (1999). Abscisic acid signal transduction in guard 
cells is mediated by phospholipase D activity. Proc. Natl. Acad. Sci. U.S.A. 96, 12192-12197. doi: 10.1073/pnas.96.21.12192

Jing, L., GuoHua, L., LiXia, H., and Xin, L. (2010). Ethylene-induced nitric oxide production and stomatal closure in Arabidopsis thaliana depending on changes in cytosolic $\mathrm{pH}$. Chinese Sci. Bull. 55, 2403-2409. doi: 10.1007/s11434-010-4033-3

Jing, L., Zhi-hui, H., Guo-hua, L., Li-xia, H., and Xin, L. (2012). Hydrogen sulfide may function downstream of nitric oxide in ethylene-induced stomatal closure in Vicia faba L. J. Integr. Agric. 11, 1644-1653. doi: 10.1016/S2095-3119(12)60167-1

Katagiri, T., Ishiyama, K., Kato, T., Tabata, S., Kobayashi, M., and Shinozaki, K. (2005). An important role of phosphatidic acid in ABA signalling during germination in Arabidopsis thaliana. Plant $J$. 43, 107-117. doi: 10.1111/j.1365313X.2005.02431.X

Khokon, M. A. R., Hossain, M. A., Munemasa, S., Uraji, M., Nakamura, Y., Mori, I. C., et al. (2010a). Yeast elicitorinduced stomatal closure and peroxidase-mediated ROS production in Arabidopsis. Plant Cell Physiol. 51, 1915-1921. doi: 10.1093/pcp/pcq145

Khokon, M. A. R., Uraji, M., Munemasa, S., Okuma, E., Nakamura, Y., Mori, I. C., et al. (2010b). Chitosan-induced stomatal closure accompanied by peroxidase-mediated reactive oxygen species production in Arabidopsis. Biosci. Biotechnol. Biochem. 74, 2313-2315. doi: 10.1271/bbb. 100340

Khokon, M. A. R., Okuma, E., Hossain, M. A., Munemasa, S., Uraji, M., Nakamura, Y., et al. (2011). Involvement of extracellular oxidative burst in salicylic acid-induced stomatal closure in Arabidopsis. Plant Cell Environ. 34, 434-443. doi: 10.1111/j.1365-3040.2010.02253.x

Kolla, V. A., and Raghavendra, A. S. (2007). Nitric oxide is a signalling intermediate during bicarbonate-induced stomatal closure in Pisum sativum. Physiol. Plant. 130, 91-98. doi: 10.1111/j.1399-3054.2007.00887.x

Kusano, T., Berberich, T., Tateda, C., and Takahashi, Y. (2008). Polyamines: essential factors for growth and survival. Planta 228, 367-381. doi: 10.1007/s00425-008-0772-7

Lamattina, L., Garcia-Mata, C., Graziano, M., and Pagnussat, G.
(2003). Nitric oxide: the versatility of an extensive signal molecule. Annu. Rev. Plant Biol. 54, 109-136. doi: $\quad$ 10.1146/annurev.arplant.54. 031902.134752

Lamotte, O., Courtois, C., Barnavon, L., Pugin, A., and Wendehenne, D. (2005). Nitric oxide in plants: the biosynthesis and cell signalling properties of a fascinating molecule. Planta 221, 1-4. doi: 10.1007/s00425-005-1494-8

Lee, and Joon-Sang. (1998). The mechanism of stomatal closing by salicylic acid in Commelina communis L. J. Plant. Biol. 41, 97-102. doi: 10.1007/BF03030395

Lee, S., Choi, H., Suh, S., Doo, I.-S., Oh, K.-Y., Choi, E. J., et al. (1999). Oligogalacturonic acid and chitosan reduce stomatal aperture by inducing the evolution of reactive oxygen species from guard cells of tomato and Commelina communis. Plant Physiol. 121, 147-152. doi: 10.1104/pp.121.1.147

Leitner, M., Vandelle, E., Gaupels, F., Bellin, D., and Delledonne, M. (2009). NO signals in the haze: nitric oxide signalling in plant defence. Curr. Opin. Plant Biol. 12, 451-458. doi: 10.1016/j.pbi.2009.05.012

Li, J.-H., Liu, Y.-Q., Lü, P., Lin, H.-F., Bai, Y., Wang, X.-C., et al. (2009a). A signalling pathway linking nitric oxide production to heterotrimeric $\mathrm{G}$ protein and hydrogen peroxide regulates extracellular calmodulin induction of stomatal closure in Arabidopsis. Plant Physiol. 150, 114-124. doi: 10.1104/pp.109.137067

Li, Y., Yin, H., Wang, Q., Zhao, X., Du, Y., and Li, F. (2009b). Oligochitosan induced Brassica napus L. production of $\mathrm{NO}$ and $\mathrm{H}_{2} \mathrm{O}_{2}$ and their physiological function. Carbohydr. Polym. 75, 612-617. doi: 10.1016/j.carbpol.2008.09.005

Li, S., Assmann, S. M., and Albert, R. (2006). Predicting essential components of signal transduction networks: a dynamic model of guard cell abscisic acid signalling. PLoS Biol. 4:e312. doi: 10.1371/journal.pbio.0040312

Lindermayr, C., Saalbach, G., and Durner, J. (2005). Proteomic identification of S-nitrosylated proteins in Arabidopsis. Plant Physiol. 137, 921-930. doi: 10.1104/pp.104.058719

Lisjak, M., Srivastava, N., Teklic, T., Civale, L., Lewandowski, K., Wilson, I., et al. (2010). A novel hydrogen sulfide donor causes stomatal opening and reduces nitric oxide accumulation. Plant
Physiol. Biochem. 48, 931-935. doi: 10.1016/j.plaphy.2010.09.016

Liu, J., Hou, Z., Liu, G., Hou, L., and Liu, X. (2012). Hydrogen sulfide may function downstream of nitric oxide in ethylene-induced stomatal closure in Vicia faba L. J. Integr. Agric. 11, 1644-1653. doi: 10.1016/S2095-3119(12)60167-1

Loake, G., and Grant, M. (2007). Salicylic acid in plant defencethe players and protagonists. Curr. Opin. Plant Biol. 10, 466-472. doi: 10.1016/j.pbi.2007.08.008

Lozano-Juste, J., and León, J. (2010). Nitric oxide modulates sensitivity to ABA. Plant Signal. Behav. 5, 314-316. doi: 10.4161/psb.5.3.11235

Lu, D., Dong, J., Jin, H., Sun, L., $\mathrm{Xu}, \mathrm{X}$., Zhou, T., et al. (2011) Nitrate reductase-mediated nitric oxide generation is essential for fungal elicitor-induced camptothecin accumulation of Camptotheca acuminata suspension cell cultures. Appl. Microbiol. Biotechnol. 90, 1073-1081. doi 10.1007/s00253-011-3146-1

Manthe, B., Schulz, M., and Schnabl, H. (1992). Effects of salicylic acid on growth and stomatal movements of Vicia faba L: evidence for salicylic acid metabolization. J. Chem. Ecol. 18, 1525-1539. doi 10.1007/BF00993226

Martínez-Ruiz, A., Cadenas, S., and Lamas, S. (2011). Nitric oxide signalling: classical, less classical, and nonclassical mechanisms. Free Radic. Biol. Med. 51, 17-29. doi: 10.1016/j.freeradbiomed.2011. 04.010

Meijer, H. J. G., and Munnik, T. (2003). Phospholipid-based signalling in plants. Annu. Rev. Plant Biol. 54, 265-306. doi: 10.1146/annurev. arplant.54.031902.134748

Melotto, M., Underwood, W., and He, S. Y. (2008). Role of stomata in plant innate immunity and foliar bacterial diseases. Annu. Rev. Phytopathol. 46, 101-122. doi: 10.1146/annurev. phyto.121107.104959

Melotto, M., Underwood, W., Koczan, J., Nomura, K., and He, S. Y. (2006). Plant stomata function in innate immunity against bacterial invasion. Cell 126 969-980. doi: 10.1016/j.cell.2006. 06.054

Moreau, M., Lindermayr, C., Durner, J., and Klessig, D. F. (2010). NO synthesis and signalling in plantswhere do we stand? Physiol. Plant. 138, 372-383. doi: 10.1111/j.13993054.2009.01308.x

Mori, I. C., Pinontoan, R., Kawano, T., and Muto, S. (2001). Involvement of superoxide generation in salicylic acid-induced stomatal closure in Vicia faba. Plant Cell Physiol. 42, 1383-1388. doi: 10.1093/pcp/pce176

Munemasa, S., Hossain, M. A., Nakamura, Y., Mori, I. C., and Murata, Y. (2011a). The Arabidopsis calcium-dependent protein kinase, CPK6, functions as a positive regulator of methyl jasmonate signalling in guard cells. Plant Physiol. 155, 553-561. doi: 10.1104/pp.110.162750

Munemasa, S., Mori, I. C., and Murata, Y. (2011b). Methyl jasmonate signalling and signal crosstalk between methyl jasmonate and abscisic acid in guard cells. Plant Signal. Behav. 6, 939-941. doi: 10.4161/psb.6.7.15439

Munemasa, S., Oda, K., WatanabeSugimoto, M., Nakamura, Y., Shimoishi, Y., and Murata, Y. (2007). The coronatine-insensitive 1 mutation reveals the hormonal signalling interaction between abscisic acid and methyl jasmonate in Arabidopsis guard cells. Specific impairment of ion channel activation and second messenger production. Plant Physiol. 143, 1398-1407. doi: 10.1104/pp.106.091298

Mur, L. A. J., Mandon, J., Cristescu, S. M., Harren, F. J. M., and Prats, E. (2011). Methods of nitric oxide detection in plants: a commentary. Plant Sci. 181, 509-519. doi: 10.1016/j.plantsci. 2011.04.003

Neill, S., Barros, R., Bright, J., Desikan, R., Hancock, J., Harrison, J., et al. (2008). Nitric oxide, stomatal closure, and abiotic stress. J. Exp. Bot. 59, 165-176. doi: 10.1093/jxb/erm293

Neill, S. J., Desikan, R., and Hancock, J. T. (2003). Nitric oxide signalling in plants. New Phytol. 159, 11-35. doi: 10.1046/j.1469-8137. 2003.00804.x

Perazzolli, M., Dominici, P., RomeroPuertas, M. C., Zago, E., Zeier, J., Sonoda, M., et al. (2004). Arabidopsis nonsymbiotic hemoglobin AHb1 modulates nitric oxide bioactivity Plant Cell 16, 2785-2794. doi: 10.1105/tpc.104.025379

Planchet, E., Gupta, K. J., Sonoda, M., and Kaiser, W. M. (2005). Nitric oxide emission from tobacco leaves and cell suspensions: rate limiting factors and evidence for the involvement of mitochondrial electron transport. Plant J. 41, 732-743. doi: 10.1111/j.1365-313X. 2005.02335.x 
Poór, P., and Tari, I. (2012). Regulation of stomatal movement and photosynthetic activity in guard cells of tomato abaxial epidermal peels by salicylic acid. Funct. Plant Biol. 39, 1028-1037. doi: 10.1071/FP12187

Raghavendra, A. S., Gonugunta, V. K., Christmann, A., and Grill, E. (2010). ABA perception and signalling. Trends Plant Sci. 15, 395-401. doi: 10.1016/j.tplants.2010.04.006

Romero-Puertas, M. C., Perazzolli, M., Zago, E. D., and Delledonne, M. (2004). Nitric oxide signalling functions in plantpathogen interactions. Cell. Microbiol. 6, 795-803. doi: 10.1111/j.1462-5822.2004.00428.x

Saito, N., Munemasa, S., Nakamura, Y., Shimoishi, Y., Mori, I. C., and Murata, Y. (2008). Roles of RCN1, regulatory A subunit of protein phosphatase $2 \mathrm{~A}$, in methyl jasmonate signalling and signal crosstalk between methyl jasmonate and abscisic acid. Plant Cell Physiol. 49, 1396-1401. doi: $10.1093 / \mathrm{pcp} / \mathrm{pcn} 106$

Saito, N., Nakamura, Y., Mori, I. C., and Murata, Y. (2009). Nitric oxide functions in both methyl jasmonate signalling and abscisic acid signalling in Arabidopsis guard cells. Plant Signal. Behav. 4, 119-120. doi: 10.4161/psb.4.2.7537

Santa-Catarina, C., Tun, N. N., Silveira, V., Handro, W., Floh, E. I. S., and Scherer, G. F. E. (2007). Rapid nitric oxide (NO) release induced by PAs in tobacco BY-2 cells and Ocotea catharinensis somatic embryos. Plant Cell Tiss. Org. 90, 93-101. doi: 10.1007/s11240-007-9259-7

Siddiqui, M. H., Al-Whaibi, M. H., and Basalah, M. O. (2011). Role of nitric oxide in tolerance of plants to abiotic stress. Protoplasma 248, 447-455. doi: 10.1007/s00709-0100206-9

Simontacchi, M., García-Mata, C., Bartoli, C. G., Santa-María, G. E., and Lamattina, L. (2013). Nitric oxide as a key component in hormone-regulated processes. Plant Cell Rep. 32, 853-866. doi: 10.1007/s00299-013-1434-1

Sirichandra, C., Wasilewska, A., Vlad, F., Valon, C., and Leung, J. (2009). The guard cell as a single-cell model towards understanding drought tolerance and abscisic acid action. J. Exp. Bot. 60, 1439-1463. doi: 10.1093/jxb/ern340

Sokolovski, S., and Blatt, M. R. (2004). Nitric oxide block of outward-rectifying $\mathrm{K}^{+}$channels indicates direct control by protein nitrosylation in guard cells.
Plant Physiol. 136, 4275-4284. doi: 10.1104/pp.104.050344

Sokolovski, S., Hills, A., Gay, R., GarciaMata, C., Lamattina, L., and Blatt, M. R. (2005). Protein phosphorylation is a prerequisite for intracellular $\mathrm{Ca}^{2+}$ release and ion channel control by nitric oxide and abscisic acid in guard cells. Plant J. 43, 520-529. doi: 10.1111/j.1365313X.2005.02471.x

Srivastava, N., Gonugunta, V. K., Puli, M. R., and Raghavendra, A. S. (2009). Nitric oxide production occurs downstream of reactive oxygen species in guard cells during stomatal closure induced by chitosan in abaxial epidermis of Pisum sativum. Planta 229, 757-765. doi: 10.1007/s00425-008-0855-5

Stöhr, C., and Stremlau, S. (2006). Formation and possible roles of nitric oxide in plant roots. J. Exp. Bot. 57, 463-470. doi: 10.1093/jxb/erj058

Suhita, D., Raghavendra, A. S., Kwak, J. M., and Vavasseur, A. (2004). Cytoplasmic alkalization precedes reactive oxygen species production during methyl jasmonate- and abscisic acid-induced stomatal closure. Plant Physiol. 134, 1536-1545. doi: 10.1104/pp.103.032250

Sun, L. R., Hao, F. S., Lu, B. S., and Ma, L. Y. (2010). AtNOA1 modulates nitric oxide accumulation and stomatal closure induced by salicylic acid in Arabidopsis. Plant Signal. Behav. 5, 1022-1024. doi: 10.4161/psb.5.8.12293

Testerink, C., and Munnik, T. (2005). Phosphatidic acid: a multifunctional stress signalling lipid in plants. Trends Plant Sci. 10, 368-375. doi: 10.1016/j.tplants.2005.06.002

Tun, N. N., Santa-Catarina, C., Begum, T., Silveira, V., Handro, W., Floh, E. I. S., et al. (2006). Polyamines induce rapid biosynthesis of nitric oxide (NO) in Arabidopsis thaliana seedlings. Plant Cell Physiol. 47, 346-354. doi: 10.1093/pcp/pci252

Umezawa, T., Nakashima, K., Miyakawa, T., Kuromori, T., Tanokura, M., Shinozaki, K., et al. (2010). Molecular basis of the core regulatory network in $\mathrm{ABA}$ responses: sensing, signalling and transport. Plant Cell Physiol. 51, 1821-1839. doi: $10.1093 / \mathrm{pcp} / \mathrm{pcq} 156$

Underwood, W., Melotto, M., and He, S. Y. (2007). Role of plant stomata in bacterial invasion. Cell. Microbiol. 9, 1621-1629. doi: 10.1111/j.14625822.2007.00938.x

Uraji, M., Katagiri, T., Okuma, E., Ye, W., Hossain, M. A., Masuda,
C., et al. (2012). Cooperative function of PLD $\delta$ and PLD $\alpha 1$ in abscisic acid-induced stomatal closure in Arabidopsis. Plant Physiol. 159, 450-460. doi: 10.1104/pp.112.195578

Vescovi, M., Zaffagnini, V., Festa, V., Trost, V., Schiavo, F. L., and Costa, A. (2013). Nuclear accumulation of cytosolic glyceraldehyde-3Phosphate dehydrogenase in cadmium-stressed Arabidopsis roots. Plant Physiol. 162, 333-346. doi: 10.1104/pp.113.215194

Wang, J. W., and Wu, J. Y. (2004). Involvement of nitric oxide in elicitor-induced defense responses and secondary metabolism of Taxus chinensis cells. Nitric Oxide 11, 298-306. doi: 10.1016/j.niox.2004.10.003

Wang, P., and Song, C. P. (2008). Guard-cell signalling for hydrogen peroxide and abscisic acid. New Phytol. 178, 703-718. doi: 10.1111/j.1469-8137.2008.02431.x

Wang, W.-H., Yi, X.-Q., Han, A.-D., Liu, T.-W., Chen, J., Wu, F.-H., et al. (2012). Calcium-sensing receptor regulates stomatal closure through hydrogen peroxide and nitric oxide in response to extracellular calcium in Arabidopsis. J. Exp. Bot. 63 , 177-190. doi: 10.1093/jxb/err259

Wang, X. (2005). Regulatory functions of phospholipase $\mathrm{D}$ and phosphatidic acid in plant growth, development, and stress responses. Plant Physiol. 139, 566-573. doi: 10.1104/pp.105.068809

Wendehenne, D., Durner, J., and Klessig, D. F. (2004). Nitric oxide: a new player in plant signalling and defence responses. Curr. Opin. Plant Biol. 7, 449-455. doi: 10.1016/j.pbi.2004.04.002

Wilson, I. D., Neill, S. J., and Hancock, J. T. (2008). Nitric oxide synthesis and signalling in plants. Plant Cell Environ. 31, 622-631. doi 10.1111/j.1365-3040.2007.01761.x

Wilson, I. D., Ribeiro, D. M., Bright, J., Confraria, A., Harrison, J., Barros, R. S., et al. (2009). Role of nitric oxide in regulating stomatal apertures. Plant Signal. Behav. 4, 467-469. doi: 10.4161/psb. 4.5.8545

Xin, L., Shuqiu, Z., and Chenghou, L. (2003). Involvement of nitric oxide in the signal transduction of salicylic acid regulating stomatal movement. Chinese Sci. Bull. 48 , 449-452.

Xin, L., Wuliang, S., Shuqiu, Z., and Chenghou, L. (2005). Nitric oxide involved in signal transduction of jasmonic acidinduced stomatal closure of Vicia faba L. Chinese Sci. Bull. 50, 520-525.

Yan, J., Tsuichihara, N., Etoh, T., and Iwai, S. (2007). Reactive oxygen species and nitric oxide are involved in ABA inhibition of stomatal opening. Plant Cell Environ. 30, 1320-1325. doi: $\quad 10.1111 / \mathrm{j} .1365-3040.2007$ 01711.x

Ye, W., Hossain, M. A., Munemasa, S., Nakamura, Y., Mori, I. C., and Murata, Y. (2013). Endogenous abscisic acid is involved in methyl jasmonate-induced reactive oxygen species and nitric oxide production but not in cytosolic alkalization in Arabidopsis guard cells. J. Plant Physiol. 170, 1212-1215. doi: 10.1016/j.jplph. 2013.03.011

Yoshioka, H., Mase, K., Yoshioka, M., Kobayashi, M., and Asai, S. (2011). Regulatory mechanisms of nitric oxide and reactive oxygen species generation and their role in plant immunity. Nitric Oxide 25, 216-221. doi: 10.1016/j.niox.2010.12.008

Zaffagnini, M., Morisse, S., Bedhomme, M., Marchand, C. H., Festa, M., Rouhier, N., et al. (2013). Mechanisms of nitrosylation and denitrosylation of cytoplasmic glyceraldehyde-3phosphate dehydrogenase from Arabidopsis thaliana. J. Biol. Chem. 288, 22777-22789. doi: 10.1074/jbc.M113.475467

Zeng, W., Melotto, M., and $\mathrm{He}$, S. Y. (2010). Plant stomata: a checkpoint of host immunity and pathogen virulence. Curr. Opin. Biotechnol. 21, 599-603. doi: 10.1016/j.copbio.2010.05.006

Zhang, B., Zheng, L. P., and Wang, J. W. (2012a). Nitric oxide elicitation for secondary metabolite production in cultured plant cells. Appl. Microbiol. Biotechnol. 93, 455-466. doi: 10.1007/s00253011-3658-8

Zhang, H., Wang, M., Wang, W., Li, D., Huang, Q., Wang, Y., et al. (2012b). Silencing of G proteins uncovers diversified plant responses when challenged by three elicitors in Nicotiana benthamiana. Plant Cell Environ. 35, 72-85. doi: 10.1111/j.1365-3040.2011.02417.x

Zhang, H., Dong, S., Wang, M., Wang, W., Song, W., Dou, X., et al. (2010). The role of vacuolar processing enzyme (VPE) from Nicotiana benthamiana in the elicitor-triggered hypersensitive response and stomatal closure. J. Exp. Bot. 61, 3799-3812. doi: $10.1093 /$ jxb/erq189 
Zhang, H., Fang, Q., Zhang, Z., Wang, Y., and Zheng, X. (2009a). The role of respiratory burst oxidase homologues in elicitor-induced stomatal closure and hypersensitive response in Nicotiana benthamiana. J. Exp. Bot. 60, 3109-3122. doi: 10.1093/jxb/ erp146

Zhang, Y., Zhu, H., Zhang, Q., Li, M., Yan, M., Wang, R., et al. (2009b). Phospholipase $\mathrm{D} \alpha 1$ and phosphatidic acid regulate NADPH oxidase activity and production of reactive oxygen species in ABA-mediated stomatal closure in Arabidopsis. Plant Cell 21, 2357-2377. doi: $10.1105 /$ tpc. 108.062992
Zhang, W., Qin, C., Zhao, J., and Wang, X. (2004). Phospholipase D $\alpha 1$-derived phosphatidic acid interacts with ABI1 phosphatase $2 \mathrm{C}$ and regulates abscisic acid signalling. Proc. Natl. Acad. Sci. U.S.A. 101, 9508-9513. doi: 10.1073/pnas.0402112101

Zottini, M., Costa, A., Michele, R. D., Ruzzene, M., Carimi, F., and Schiavo, F. L. (2007). Salicylic acid activates nitric oxide synthesis in Arabidopsis. J. Exp. Bot. 58, 1397-1405. doi: 10.1093/jxb/erm001

Zweier, J. L., Samouilov, A., and Kuppusamy, P. (1999). Nonenzymatic nitric oxide synthesis in biological systems. Biochim. Biophys. Acta 1411, 250-262. doi: 10.1016/S0005-2728(99)00018-3

Conflict of Interest Statement: The authors declare that the research was conducted in the absence of any commercial or financial relationships that could be construed as a potential conflict of interest.

Received: 17 July 2013; accepted: 08 October 2013; published online: 29 October 2013.

Citation: Gayatri G, Agurla $S$ and Raghavendra AS (2013) Nitric oxide in guard cells as an important secondary messenger during stomatal closure.
Front. Plant Sci. 4:425. doi: 10.3389/fpls. 2013.00425

This article was submitted to Plant Physiology, a section of the journal Frontiers in Plant Science.

Copyright (c) 2013 Gayatri, Agurla and Raghavendra. This is an open-access article distributed under the terms of the Creative Commons Attribution License (CC BY). The use, distribution or reproduction in other forums is permitted provided the original author(s) or licensor are credited and that the original publication in this journal is cited, in accordance with accepted academic practice. No use, distribution or reproduction is permitted which does not comply with these terms. 